\title{
The influence of principal managerial and work motivation toward teacher performance
}

\author{
Umar Paruq $^{1}$, Yasir Arafat ${ }^{2}$, Alhadi Yan Putra2 ${ }^{3}$ \\ ${ }^{1}$ Sekolah Menengah Atas Negeri 1 Mekakau Ilir, Indonesia \\ ${ }^{2}$ Universitas PGRI Palembang, Indonesia
}

\section{Article Info \\ Article history: \\ Received Jul 21 ${ }^{\text {th }}, 2021$ \\ Revised Aug $14^{\text {th }}, 2021$ \\ Accepted Aug $30^{\text {th }}, 2021$ \\ Keyword: \\ Principal Managerial \\ Work Motivation \\ Teacher Performance.}

\begin{abstract}
Study aims to determine managerial influence of principals and work motivation toward teacher performance. Type of research was quantitative study using t-test and F-test. Sample was hundred of teachers. Data collection technique used questionnaire. Data analysis technique used SPSS program. Results of study (1) Principal managerial had significant influence toward teacher performance. This was evidenced by the t-count 13.998 and t-table 1.660 ; (2) Work motivation had significant influence toward teacher performance according to t-count 2.206 and t-table 1.660; (3) Principal managerial and work motivation had a significant influence toward teacher performance, based on the test results obtained F-count value 4.653 and Ftable 3.09. There was a significant influence between principal managerial and work motivation towards teacher performance.
\end{abstract}

C 2021 The Authors. Published by IICET.

This is an open access article under the CC BY-NC-SA license (https://creativecommons.org/licenses/by-nc-sa/4.0

\section{Corresponding Author:}

Paruq, U.,

Sekolah Menengah Atas Negeri 1 Mekakau Ilir, Indonesia

Email: umarsupie@gmail.com

\section{Introduction}

One of the important factors that has role in formation of personality and improving the quality of human resources is education. It takes support from the government and stakeholder educational actors in order to create the quality of education quality and reliable [1].

The importance of education is in line with its functions and benefits, namely providing quality human resources for developing the nation and state. Self-potential can be increased and developed such as personality, intelligence, skills, and broad insight through education. The challenges of science and technology which develop rapidly caused in growth and changes in complex directions. It can cause new problems and demands that were previously unpredictable, so that education always faces obstacles due to gaps between what is expected and the results obtained in the education process itself [2].

In carrying out its main duties and functions, a teacher has important task and function that main in order to create a good quality in education. Acting as professionals who have the duty of learning plan, implementing in learning, providing the value, providing guidance to students coupled with community service, as well as role models for the surrounding community in good attitude and behavior [3].

It takes hard and comprehensive efforts from various fields to improve the quality of professional teachers. Improvement in this direction requires sustainable development with adequate planning. In addition, the attention and respect for the professionalism of a teacher must be appreciated. In achieving this, teacher 
competence is not only assessed from the aspect of providing training, upgrading, and learning opportunities to a higher level, but from other aspects, in this case the level of discipline and work motivation of the teacher [4].

As the spearhead in the world of education, teachers have advantages and disadvantages that is why the role of the principal in leading as a motivator is expected to be able to foster and be responsible for obtaining maximum results in accordance with the vision and mission in the school. The important thing in increasing the work motivation of the teacher itself is to be able to provide the best for students in teaching and learning activities in the classroom so that they become humans who can make the name of the school in particular and the name of education in general proud [3].

In fostering motivation to work for teachers in schools, the principal must play an active role by making concepts that have been arranged in his main task. As a managerial person, the principal must be an example or role model for teachers so that teachers feel respectful and reluctant to act. As a person who makes decisions and determines a policy, the principal has a very central role in seeking to improve the performance of his subordinates [3].

The results of [5] research show that teachers' perceptions of principal managerial model and teacher motivation together have a positive effect on teacher performance. In accordance with [6] the managerial types of school principals are varying, some are maximal and some are not maximal. The managerial that maximumwill create a conducive work environment, so that teacher work motivation higher will arise. Teacher work motivation is a boost from within and a push from outside a teacher to carry out work. In conclusion, work motivation can be one of the factors that can affect the ups and downs of teacher performance. Therefore, the maximum managerial level of school principals and the amount of teacher work motivation is needed in order to achieve educational and organizational goals in schools. It is evident from the results of [7] research which shows that the principal's transformational leadership and work motivation have a significant effect on teacher performance.

Research conducted by [8], regarding managerial competencies that have been applied by school principals in order to build teacher work motivation found the comfort and enthusiasm of teachers in carrying out their daily tasks, namely teaching and educating at the school. It can be seen from the harmonious relationship that exists between the teachers and the teacher's attendance level in providing learning in the classroom. [9] aims to analyze the implementation process of the principal's managerial abilities and to find out the principal's managerial strategies in improving teacher performance. This condition is caused by the lack of supervision by the principal on teacher performance, lack of motivation, and the use of monotonous learning methods. So, from these conditions, it is necessary how the implementation process and managerial strategies of school principals in improving teacher performance.

Some of the previous studies that have been described above, furthermore, having similarities with this study, are the principal managerial variables, work motivation, and teacher performance, but also have differences, namely the type of research and the place of research. The types of research above are qualitative research and correlation research, while this research is quantitative research. The research site was chosen in Mekakau Ilir District, furthermore, having never been used as a research site, because one of the school principals in an elementary school in Mekakau Ilir District was the first winner in the 2020 Achievement Principal Competency Test in Ogan Komering Ulu Selatan Regency.

From the description above, researchers need to conduct research to prove whether there is a significant effect of principal managerial and work motivation on teacher performance. The results of preliminary observations made on several State Elementary Schools in the District of Mekakau Ilir, generally the principals have good managerial skills and the teachers also have good work motivation. This is indicated by the attendance at school on time, the effective use of teaching and learning time and school activities, and preparing a lesson plan before the implementation of learning in class takes place. However, in practice, there are classroom and subject teachers who are still not performing well.

Based on the background of the problem, it can be used as the initial basis for researchers to conduct further research and raise it as material for a thesis entitled "Principal Managerial Influence and Work Motivation on Teacher Performance."

\section{Method}

This research is a type of quantitative research. [13] which includes quantitative research methods are survey and experimental methods. In accordance with the problems and objectives that have been formulated, this 
research is designed as a survey method research where the research technique is the information collected through a questionnaire.

Causal analysis used as a causal research design, aims to prove the relationship that affects and is influenced (causal relationship) of a number of variables studied, namely principal managerial variables and work motivation with teacher performance variables. Thus it can be investigated the relationship between the dependent variable and the independent variables so that the hypothesis can be tested empirically and through statistical analysis.

The research was conducted in October-December 2020. The population in the study were all State Elementary Schools teachers in Mekakau Ilir sub-district, totaling 183 people. The sampling technique used in this study was the Simple Random Sampling Technique, that is, from the total population, 100 samples were determined as the research object. The data was collected using a questionnaire using a Likert scale which was previously calibrated by an expert, validity and reliability tests. The prerequisite stage of the analysis includes the normality test, linearity test, and data multico linearity test. The research hypothesis test used descriptive data, $t$ test, $F$ test, and the coefficient of determination.

\section{Results and Discussions}

Data descriptions are useful for explaining the distribution of data by frequency, for explaining intermediate trends, and for explaining the distribution pattern (maximum-minimum). To test the descriptive analysis of the data in this study, this research was carried out by using the SPSS version 25 program. The data descriptions in this study are as follows:

Principal managerial variables in this study consist of seven dimensions of indicators, namely moving, influencing, motivating, inviting, directing, guiding/fostering, advising, and supervising subordinates. The results of the descriptive analysis of data on the principal managerial variables are as follows:

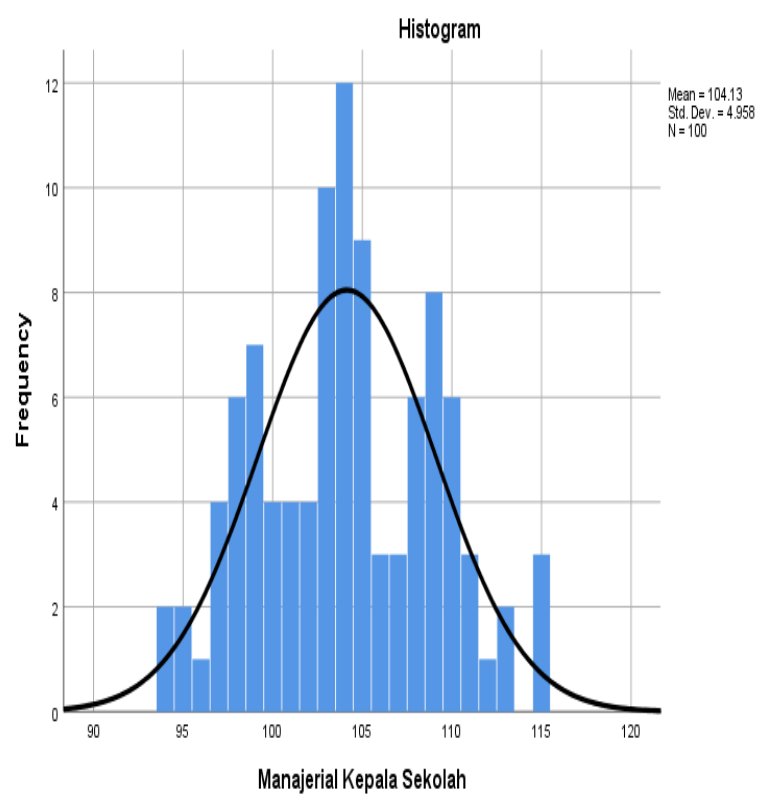

Figure 1.Histogram of Principal's Managerial Effect Score on Teacher Performance (Source: Results of SPSS Version 25)

The chart shows that the principal managerial is in the sufficient category. This can be seen from the distribution in the middle of the histogram, there is a significant influence of the principal managerial variables on teacher performance.

The work motivation variable in this study consists of the dimensions of inner motivation, namely responsibility in carrying out tasks, carrying out tasks with clear targets, independence in acting, having a feeling of pleasure at work, and achievement. As well as the dimension of motivation from outside ourselves, namely trying to meet needs, opportunities for promotion, obtaining recognition, and working in the hope of getting a decent reward. The results of the descriptive analysis of data on work motivation variables are as follows: 


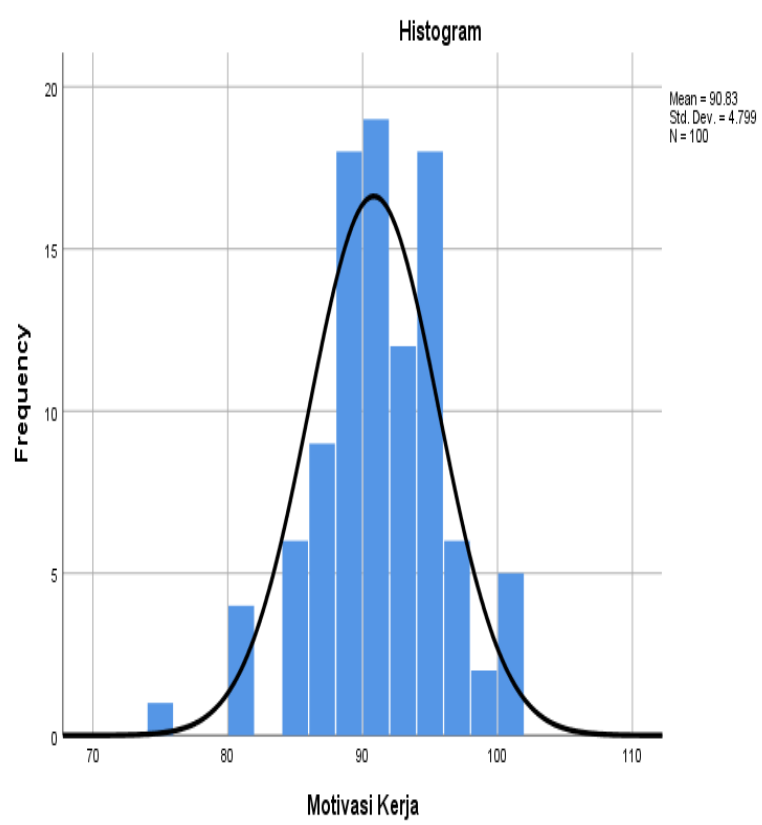

Figure 2. Histogram Score of the Effect of Work Motivation on Teacher Performance (Source: Results of SPSS Version 25)

The chart identifies that the work motivation is in the sufficient category It can be seen from the distribution in the middle of the histogram, there is a significant influence on the work motivation variable on teacher performance.

Teacher performance variables in this study consisted of six indicator dimensions, namely educating, teaching, guiding, training, assessing, and evaluating. The results of the descriptive analysis of data on teacher performance variables are as follows:

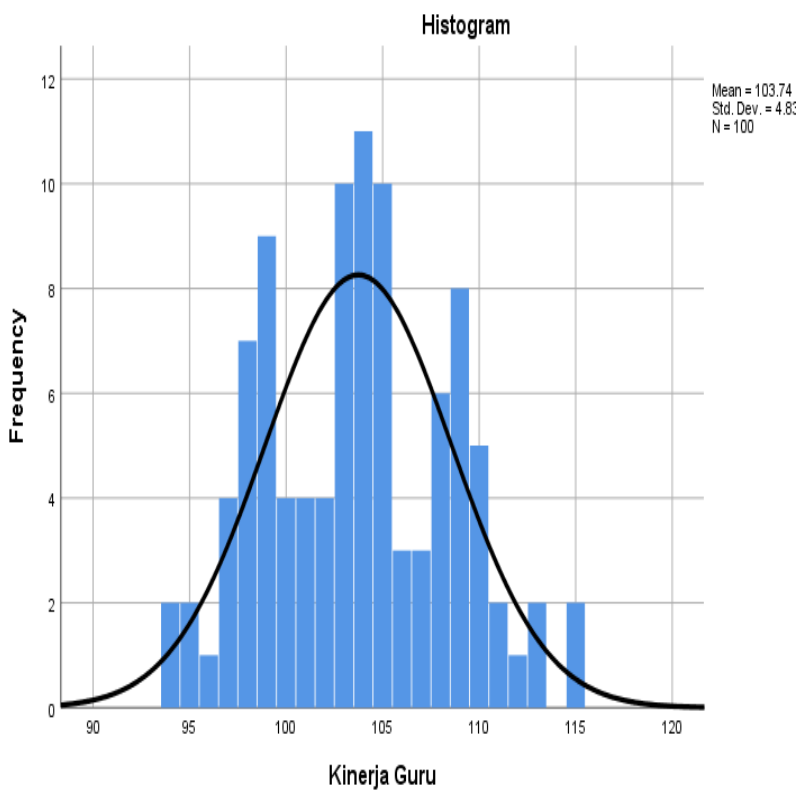

Figure3. Histogram of Principal Managerial Influence Score and Work Motivation on Teacher Performance (Source: Results of SPSS Version 25)

From the chart it is known that the data is normally distributed because the curve is symmetrical. This identifies that the teacher's performance is in the sufficient category. It can be seen from the distribution in the middle of the histogram that there is a significant influence on the principal managerial variables and work motivation on teacher performance. 
Normality test is used to determine the condition of the data obtained with normal distribution or vice versa. Data normality testing can use thetest statistic Kolmogrof-Smirnov calculated with the help of SPSS The testing criteria with Kolmogrof-Smirnov testare if the probability value (significant) $>\alpha=0.05$ then the data is said to be normally distributed and if the probability value (significant) $<\alpha=0.05$ then the data is said to be not normally distributed [10].

Data normality testing was carried out using thetechnique Kolmogrof-Smirnov Test (z). This test criterion is if the significance obtained is $>0.05$, then the sample is from a normally distributed population. Conversely, if the significance obtained is $<0.05$, the sample does not come from a normally distributed population.

Table 1.Test of Normality

\begin{tabular}{|l|r|r|r|}
\hline \multirow{2}{*}{} & \multicolumn{3}{|c|}{ Tests of Normality } \\
\cline { 2 - 4 } & Statistic & df & Sig. \\
\hline Manajerial Kepala Sekolah & .080 & 100 & .111 \\
\hline Motivasi Kerja & .078 & 100 & .142 \\
\hline Kinerja Guru & .087 & 100 & .061 \\
\hline a. Lilliefors Significance Correction & & & \\
\hline (Source: Results of SPSS Version 25) & & & \\
\end{tabular}

From the calculation of the normality test in the table above, it is known that the principal managerial variables and work motivation on teacher performance can be concluded: a.)Principal managerial data (X1) has a significance value of $0.111>0.05$, so the data is declared to be normally distributed. $b$.) Work motivation data (X2) has a significance value of $0.142>0.05$, so the data is declared to be normally distributed.c.)Teacher performance data $(\mathrm{Y})$ has a significance value of $0.061>0.05$, so the data is declared to be normally distributed.

Linearity test is used to determine whether the data obtained is linear or not. The linearity test uses theanalysis test technique One-Way Anova on the SPSS program. With the criteria if the significance value on theline is Linearity $\geq 0.05$ then the relationship between variables is linear and if the significance value on theline is Linearity $<0.05$ then the relationship between variables is not linear [10].

Linearity test in this study used the test for linearity with the SPSS version 25 program with the following assumptions:(a) If the significance value on theline is Linearity $\geq 0.05$ then the relationship between variables is linear. (b) If the significance value on theline Linearity $<0.05$ then the relationship between variables is not linear.

The results of data analysis can be seen in the following table:

Table 2.Linearity Test

ANOVA Table

\begin{tabular}{lllrrr} 
& & Sum of Squares & df & \multicolumn{1}{c}{ Sig. } \\
\hline Kinerja & Between Groups & (Combined) & 488.739 & 20 & .407 \\
$\begin{array}{l}\text { Guru * } \\
\text { Manajerial }\end{array}$ & & & & \\
\cline { 2 - 6 } $\begin{array}{l}\text { Kepala } \\
\text { Sekolah }\end{array}$ & Linearity & 23.400 & 1 & .317 \\
\cline { 2 - 6 } & Within Groups & Deviation from Linearity & 465.339 & 19 & .404 \\
\cline { 2 - 6 } & Total & & 1820.501 & 79 & \\
\hline
\end{tabular}

From the results of data analysis using the SPSS version 25 program, it can be argued that the significance value on theline is Linearity $\geq 0.05$, for the principal managerial variable $0.317 \geq 0.05$ and the work motivation 
variable $0.467 \geq 0.05$, thus the relationship between head managerial variables school and work motivation with teacher performance is stated to be linear.

[11] Multicollinearity test test was conducted to prove or test whether the regression model found a correlation between the independent variables. In multiple linear regressions, there are two or more independent variables that are thought to affect the dependent variable, this assumption can be justified if there is no linear relationship (multicollinearity). A good regression model should not find a correlation between the independent variables. To determine whether there is a multicolonierity problemin the regression model, it is seen from the VIF (Variance Inflatation Factor) value obtained with the condition that if thevalue is tolerance $>0.10$ and the VIF value is $<10.00$, it means there is no multicolonierity. Meanwhile, if thevalue tolerance $\leq$ 0.10 and the VIF value $>10.00$, it means that there is multicolonierity.

Table 3.Multicollinearity Test Data

\begin{tabular}{llll}
\hline & \multicolumn{2}{c}{ Coefficients $^{\mathbf{a}}$} \\
\hline \multirow{2}{*}{ Model } & \multicolumn{2}{c}{ Collinearity Statistics } \\
\cline { 2 - 4 } & (Constant) & Tolerance & VIF \\
\cline { 2 - 4 } & & 3.031 \\
\cline { 2 - 4 } & Manajerial Kepala Sekolah & .330 & 3.031 \\
\cline { 2 - 3 } & Motivasi Kerja & .330 & \\
\hline
\end{tabular}

a. Dependent Variable: Kinerja Guru

From the results of data analysis using the SPSS version 25 program, it can be seen that the variable has a tolerance value $>0.10$ and a VIF value $<10.00$ so it can be concluded that there is no multico-linearity between the independent variables.

Hypothesis testing was continued after testing the data analysis requirements, namely the normality test, linearity test, and data multico-linearity test. After the data is declared to have met the requirements to be tested, then the hypothesis is tested using the $\mathrm{t}$ test and the $\mathrm{F}$ test, to determine the effect partially and simultaneously on the variables to be tested.

Hypothesis test is a test to determine the principal managerial relationship to teacher performance. The first hypothesis to be tested for truth is:

Ha1: There is a significant managerial influence of the principal on teacher performance

Ho1: There is no significant managerial effect of the principal's manager on teacher performance

And the statistical hypothesis test formulation is as follows:

$\mathrm{H} 01$ is rejected if $\mathrm{t}$ iscount $>$ ttable

$\mathrm{H} 01$ is accepted if tcount $\leq$ ttable

For the results of hypothesis testing can be presented in the following table:

Table 4. Results of t-test analysis for managerial variables of the principal on teacher performance

\section{Coefficients $^{\mathrm{a}}$}

\begin{tabular}{llrr}
\hline \multicolumn{2}{l}{ Model } & \multirow{2}{*}{ S } & Sig. \\
\hline \multirow{2}{*}{\begin{tabular}{l} 
(Constant) \\
\cline { 2 - 4 }
\end{tabular}} & Managerial Principals & 2,256 &, 026 \\
\hline
\end{tabular}

a. Dependent Variable: Teacher Performance 
Based on the results of the $t$ test above, it is found that the significance value is 0.000 . Because the significant value (probability) is less than 0.05 and the $t$ value is $13.998>t$ table 1.660 , it can be concluded that $\mathrm{H} 01$ is rejected, which means that the principal managerial has a significant effect on teacher performance.

Hypothesis test is a test to determine the relationship between work motivation and teacher performance. The second hypothesis to be tested for truth is:

$\mathrm{Ha} 2$ : There is a significant effect of work motivation on teacher performance

Ho2: There is no significant effect of work motivation on teacher performance

And the statistical hypothesis test formulation is as follows:

$\mathrm{H} 02$ is rejected if tcount $>$ ttable

HO2 is accepted if tcount $\leq$ ttable

For the results of hypothesis testing can be presented in the following table:

Table 5.Results of t-test analysis of work motivation variables on teacher performance

\section{Coefficients $^{\mathrm{a}}$}

Model

1

(Constant)

Work Motivation
Sig.

2,256 , 026

2,206

a. Dependent Variable: Teacher Performance

Based on the results of the $t$ test calculation above, it is found that the significance value is 0.030 . Because the significant value (probability) is less than 0.05 and the $t$ value is $2.206>t$ table 1.660 , it can be concluded that $\mathrm{H} 02$ is rejected, which means that there is a significant influence between work motivation on teacher performance.

Hypothesis test is a test to determine the managerial relationship of school principals and work motivation together (simultaneously) on teacher performance. The third hypothesis that will be tested for truth is:

Ha3: There is a significant managerial influence of school principals and work motivation together on teacher performance

Ho3: There is no significant effect of principal managerial and work motivation together on teacher performance

And the statistical hypothesis test formula is as follows:

$\mathrm{H} 03$ is rejected if $\mathrm{F}_{\text {count }}>\mathrm{F}_{\text {table }}$

$\mathrm{H} 03$ is accepted if $\mathrm{F}_{\text {count }} \leq \mathrm{F}_{\text {table }}$

For the results of hypothesis testing can be presented in the following table:

Table 6.Regression Analysis Results

\begin{tabular}{llcrl}
\hline \multicolumn{3}{c}{ ANOVA $^{\mathrm{a}}$} & & \\
\hline \multirow{2}{*}{ Model } & & $\mathrm{F}$ & Sig. & \\
\hline \multirow{2}{*}{1} & Regression & 4,653 & $202,147^{\mathrm{b}}$ \\
\cline { 2 - 4 } & Residual & & & \\
& & &
\end{tabular}


Total

a. Dependent Variable: Teacher Performance

b. Predictors: (Constant), Work Motivation, Principal Managerial

Based on the above values, it is known that the significance value for the managerial effect of school principals and work motivation simultaneously or together on teacher performance is $0.012<0.05$ and the value of F count $4.653>\mathrm{F}$ table 3.09 , so it can be concluded that H03 is rejected, which means that there is a significant influence between managerial principal and work motivation together on teacher performance.

The coefficient of determination is a test to determine how much influence the independent variables (principal managerial and work motivation) have on the independent variable (teacher performance) simultaneously.

For the test results the coefficient of determination can be presented in the following table:

Table 7.Results of the Principal Managerial Determination Coefficient (X1) and Work Motivation (X2) on Teacher Performance (Y)

Model Summary

\begin{tabular}{|c|c|c|c|}
\hline Model & $\mathrm{R}$ & R Square & Adjusted R Square \\
\hline 1 & $.847^{\mathrm{a}}$ & .717 & .711 \\
\hline
\end{tabular}

a. Predictors: (Constant), Work Motivation, Principal Managerial

b. Dependent Variable: Teacher Performance

Table 7 shows the magnitude of the value of $\mathrm{R}$ Square, namely 0.717 thus the coefficient of determination is $71.7 \%$, so it can be concluded that the influence of the independent variables (principal managerial and work motivation) on the dependent variable (teacher performance) together is equal to $71.7 \%$ and the remaining $28.3 \%$ is influenced by other factors that are not research variables such as teacher education level, teaching supervision, upgrading program, conducive climate, facilities and infrastructure, teachers' physical and mental condition, principal leadership style, welfare guarantees, and others [12]

\section{Conclusions}

Based on the results of the research that has been done, it is concluded that there is a significant influence of school principal managerial and work motivation towards state elementary school teachers performancein Mekakau Ilir District. With a good managerial principal, it will improve teacher performance because managerial is a tool to achieve goals, one of which is that teachers have good performance. Work motivation in the learning process is an important part in supporting the creation of the educational process, especially in achieving teacher performance. Good work motivation will improve teacher performance. With the principal managerial and good work motivation, correlated together, it will be very supportive to improve teacher performance. 


\section{References}

Slameto. (2010). Belajar dan Faktor-Faktor Yang Mempengaruhi. Jakarta: Rineka Cipta.

Syah, M. (2010). Psikologi Pendidikan dengan Pendekatan Baru Edisi Revisi. Bandung: PT. Remaja Rosdakarya.

Umami, S., Lian, B., \& Missriani. (2020). Pengaruh Manajerial dan Motivasi Kerja Guru Terhadap Disiplin Kerja. Jurnal Manajemen, Kepemimpinan, dan Supervisi Pendidikan, Volume 6, No 1, Januari-Juni 2021.

Tirtarharja,\& Sulo. (2012). Pengantar Pendidikan. Jakarta: Rineka Cipta.

Retyasari, R. A. (2017). Persepsi Guru Tentang Pola Manajerial Kepala Sekolah dan Motivasi Guru Terhadap Kinerja Guru Sekolah Menengah Pertama Negeri Se Kecamatan Banjarejo Kabupaten Blora Tahun Ajaran 2016/2017. Surakarta: Universitas Muhammadiyah Surakarta.

Palupi, R. (2016). Pengaruh Kepemimpinan Kepala Sekolah dan Motivasi Kerja Guru Terhadap Kinerja Guru Sekolah Dasar Negeri Gugus Wiratno Kecamatan Cilacap Tengah. Semarang: Unnes.

Latan, dkk. (2013). Analisis Multivariate Teknik dan Aplikasi Menggunakan IBM Spss 20,0. Bandung: Alfabeta.

Tobing, F. W. R. L. (2018) Kompetensi Manajerial Kepala Madrasah Dalam Membangun Motivasi Kerja Guru di MAS PAB-2 Helvetia. Medan: UIN Sumatera Utara.

Weli, E. E. (2019). Implementasi Kemampuan Manajerial Kepala Sekolah Dalam Meningkatkan Kinerja Guru di MTs N 2 Mukomuko. Bengkulu: IAIN Bengkulu.

Kesumawati \& Aridanu. (2017). Statistik Parametrik. Palembang: NoerFikri Offset.

Dwi, P. (2009). Mandiri Belajar SPSS. Jakarta: Bumi Kirta.

Hikmat. (2009). Manajemen Pendidikan. Bandung: Pustaka Setia.

Sugiyono. (2019). Statistika Untuk Penelitian. Bandung: Alfabeta. 